\title{
The Semantics of Russian Life at the Lessons \\ of Russian as a Foreign Language: \\ Linguistic and Methodological Aspects \\ (a Case Study)
}

\author{
Tatiana V. Tarasenko* \\ Siberian State Aerospace University \\ 31 Krasnoyarskii rabochii, Krasnoyarsk, 660014, Russia
}

Received 06.10.2014, received in revised form 11.11.2014, accepted 21.12.2014

This article is dedicated to the semantics of Russian life through the situation of alcohol drinking, and analysis of the linguistic aspect of the situation of alcohol drinking, the technique of studying the situation at the lessons of Russian as the foreigner language.The material used was the stories, plays by A.P. Chekhov.

Keywords: situation, semantic, A.P. Chekov plays, everyday life, lessons of Russian as the foreigner language.

Research area: philology.

\section{Introduction}

Everyday life as a category is often considered by philosophers than linguists, because it is an essential characteristic of the human existence. According to Heidegger, existentialism considers the category of existence as a presence, a life in reality, and this presence itself is meaningful and significant (Shor, 2005: 6). Linguists' interest in daily life is connected, first of all, with practical goals and then with scientific curiosity. Study of foreign languages begins from learning a surrounding everyday life on the lexical level. From our point of view, we should study the life and culture not only in terms of vocabulary (lexis), but also in terms of semantics. Therefore, everyday life consideration of another language's native speaker through the prism of semantic situation, allows us to look at the current life and its reflection in the language from different perspective. This allows a foreigner not only to learn a list of lexical items, but to learn a language in action, in knowledge, in comparison with the native language. As the part of the semantic approach to the language, examination and reconstruction of the linguistic picture of the world is carried out by describing such unit as a semantic situation, because various elements of extra-linguistic reality are reflected in it. Postulating the correlation and mutual influence of language and culture, it is possible to think over the possibility of examine the phenomenon of the material culture in linguistics,

(C) Siberian Federal University. All rights reserved

* Corresponding author E-mail address: tvt2004@mail.ru 
theory of translation and cultural linguistics. Such phenomenon includes the situation of alcohol drinking or drinking alcoholic beverages. Being an integral part of everyday life, alcohol drinking takes a special place in the national picture of the world. One the one hand, our aim is to show the specific of the situation of alcohol drinking and its language representations in the different text types from linguistics position (semantic syntax) in Russian; on the other hand, to examine the methods of teaching of the present situation at the lessons of Russian as foreign language.

\section{Stereotypes about Russians}

In cross-cultural communication the use of stereotypes - the simplest form of communication that represents the simplified presentations of the ethnic groups about each other. So the main qualities of the Englishman in the terms of native Russian speakers are courtesy, restraint and punctiliousness. For the representatives of other cultures Russian is associated with a typical set of stereotypes that, in their opinion, reflects the national character of the Russian people: reckless (dare-devil), generous and lazy. Love for alcohol encloses the ten characteristic features of the Russian people. According to the Americans, the Russians are gloomy, sullen and prone to immoderate consumption of vodka (Kobozeba, 2002: 185). That is a typical ethnic stereotype and to be more precise, heterostereotype (Vasiliev, 2002). What is Russia? No responsibility and the ocean of vodka!" That is how Arthur Solomonov - a journalist and blogger - called his article about a performance on Moscow stage of the polish Modzheevski Theatre from the Legnica city. "The famous Polish director and his actors presented the play "The Siberian Tale" which showed what the Poles think about Russia and Poland. There were no sensations - the Poles think about their homeland in very good terms, thoughts about Russia are quite reverse. <..>
And Russians: Grushenka - "A Russian beauty, a local girl", Yevgeny - "A Russian vagrant and an alcoholic" ... See? If it's a Russian beauty she is a whore, if it's a Russian guy - he is an alcoholic. And what words were babbled from the stage? "No responsibility and the ocean of vodka. Russia"...”Bloody hell ghost of damned Russia in the damned haze"... "Russian can not express high and subtle feelings" ... "Moscow in comparison with Warsaw - just a village"...<... The movement - a surrender towards to the so uncompromising theme that were stated. One of the characters after drinking vodka with mushrooms (in Siberia even such kind exists) sings a hymn to an international friendship. <..> It is worth noticing that the Sabbath reconciliation occurred only after the moment when the Russian and Poles drank vodka. Vodka with mushrooms. So maybe this friendship is no more than a hallucination? Perhaps conciliatory conversations are possible only under the mushroom vodka steams? “ (Slon.ru.16.01.2010).

A weakness for the bottle is a popular stereotype (hetero and auto one) about Russians.

\section{Stereotypes and Russian Life in Anecdotes}

The Subject of alcohol drinking is traditional for the Russian literature. According to Yu. Schegoleva auto stereotype's (the stereotypes that people have about themselves) origins lie in the archetypal images of the heroic epic, "a true hero is a brave and even daring warrior, he does not use any magic, he is ready to face any danger and prone to overestimate his strength" (Shegoleva, 2006: 194). Archetypal motifs can also be found in the literature. Thus the image of Taras Bulba and other Sichovykh Cossacks are traced in the images of warriors, "of the generous Russian nature": "Drink and carouse, as only a Russian can $<_{\text {... }}>$ Russian character here is a powerful, of wide-ranging enterprise and a stalwart 
appearance” (Nikolai Gogol. "Taras Bulba). Making a wrongful accusation against Chatsky, Famusov's guests see the cause of insanity in an alcohol:

\section{Хлестова.}

В его лета с ума спрыгнул!

Чай, пил не по летам. 〈...〉

Шампанское стаканами тянул.

Наталья Дмитриевна.

Бутылками-с, и пребольшими.

Загорецкий (с жаром).

Нет-с, бочками

сороковыми

(А. Грибоедов. Горе от ума).

As auto stereotype the alcohol drinking is widely represented in the cultural environment of the modern Russian man: a mass literature, a cinema, songs, etc., including the anecdote, for example: Идут международные соревнования по употреблению спиртных напитков. На сиене стоят стаканы, ведра и бочки. Комментатор ведет репортаж: - Вот выходит на сиену английский спортсмен. Он выпивает стакан. Затем бутылку, подходит $\kappa$ ведру и... падает. Выходит франиуз. Выпивает стакан. Бутылку! Выпивает полведра... Эх! Падает... После паузы ведущий продолжает: - На сиене русский богатырь! Поиграв мускулами, он поднимает бочку и, не торопясь, выпивает ее до дна, затем ведро, потом бутылку (Tarasenko, 2004: 2005).

The situation of alcohol drinking (hereinafter referred to as SoAD) in the terms of semantic syntax is included in the group of «action» situations, is a physiological action and has the following model: a subject - verb of the physiological action - an object: a person gulps down some liquid, for example: Ivan Timofeevich drank almost the whole earthenware pot, undressed and lay down (V. Voinovich) (Russian verbal sentences, 2002: 155). Therefore, the following components further will be taken into consideration: the participants (who drinks alcoholic drinks), the object (beverage), the place and the time.

Analysis of the anecdotes that represent situation of alcohol drinking showed the following: the subject of the alcohol drinking is a person, an animal, an object, a fantastic character. For a man as a hero of the anecdote stories the following characteristics are important: a gender, a marital status and kinship, a nationality, an occupation, how much this person drinks, that is why in the anecdotes the hero is a man more often that a women. By the quantity of alcohol drinking he may have the following nominations: a teetotaler; a dilettante (drinks on holidays or special occasions); a boozer / bukharchik (drinks more than a elbow-bender); a drunk / drunkard (abuse of alcohol), an alcoholic / drunkard (sick people suffering from alcoholism).

There are the anecdotes about the drinking animals: a wolf, a bear, a rabbit, a mouse, a frog, etc. The fairy-tale characters are represented by Baba-Yagoy, Ivan the Fool, and Ilya of Muromets.

The members of ethnic groups in the anecdote are following: Russian, Jewish, Scottish, French and English.

Among the professional groups leading are the surgeons, the mechanics, the hunters, the soldiers and the priests.

In addition to the main subjects there is another minor subject in the anecdotes about situation of alcohol drinking. The minor subject is a subjective type of person, nonunique, located with other subject in the parallel relationship; the main subject and the minor subject perform multidirectional action (Shmelova, 1988: 46).

The role played by the minor subject is an opponent of drunkenness, in anecdotes represented by a wife (or/and a mother-in-law), for instance: Идет пьяный мужик по улице и заходит к себе во двор. Видит, в кустах сидит 
кукушка. Он говорит: - Кукушка, кукушка. Сколько мне лет осталось жить? Тут из окна высовывается жена: - Пять - семь секунд... пока я утюг не нашла.

The subject can also be characterized by the amount of the alcohol that the person can drink alone, but more often it happens in the company of drinking companions, whose numbers are classical - three persons: Встретились двое и стали искать третьего, чтобы выпить. Скажи, а в Африке тоже пьют?

- Пьют.

- А как, по-нашенски? Тоже на троих соображают?

- Да, только двое пьют, а третьим закусывают.

Why there are three of them? Because it is more funny and economically beneficial. The researchers note that collectivity of situation of alcohol drinking has a long tradition: "The more visitors and people attend the party and drink with hem, the better, the funnier he gets" ([Stepanov, 2001: 302).

It is easy to guess the object of alcohol drinking in a Russian anecdote - it is vodka. On the other hand there are other views about the Russian national drink. The researcher of Russian culture V. V. Pokhlebkin believes that the national drink is tea: «The Russian drama rather convincingly answers to such a perpetually controversial and sensitive for national pride issue - what is considered to be a Russian national drink - tea (besides Chinese tea...) or vodka - our own product and invention? The answer is unequivocal - tea. Why? Because tea is drunk in all Russian plays from the eighteenth century to the present day ... We drink tea not only continuously, not only throughout the history of Russian drama, all classes of Russian society one after another drink tea, eventually turning tea into a nationwide beverage, «classless drink. Exactly in this capacity tea is represented as a unique and certainly a national phenomenon «(Pochlebkin, 1995: 453).

In the anecdote vodka has two characteristics: good and very good, it also can be represented metonymically - half-liter (half-liter bottle), a quarter-liter bottle of vodka, a small bottle. The second place is for the a beer, the third is for a cognac, champagne and wine. Among the drinks you can also find an ethyl alcohol, a home-distilled vodka, a rum, a cologne and a windscreen wiper. The choice of the drinks depends on the taste preferences (for example, the hussars in the anecdote drink only a champagne) or a social (material) status: $y$ винного прилавка шикарная дама выбирает белое вино к лососине, красное - к оленине на вертеле, коньяк - к кофе и т.n. Когда, наконеи, она закруглилась, стоящий сзади мужчина с остервенением потребовал: $A$ мне пол-литру калужского разлива. $K$ мойве в томате. Or $B$ парфюмерном магазине помятый мужичок обращается $к$ продавщиие: - Два тройных и «Гвоздику»!

They drink vodka straight from the bottle (i.e., without any vessels, bottles), from the glasses, the goblets and the wine glasses, the shot glasses, although the drinking vessels are well represented in the literature (see, for example, the names and quantities of vodka's vessels: (Levontina, 2009)).

The time of drinking dose not really matter. Typically, the time characteristic is given on the time of day or on other actions, such as: а) Едет утром в троллейбусе мужик и его качает; б) - Папаня, баня уже топится. Вы сейчас выкушаете стопочку или после бани?

The location can also be anywhere - the one thing that amazed is the choice of places and breadth of choice: a street, the public places, including the playgrounds, means of transport (a plane, a train, a bus, a taxi and a car). 
In the anecdote the street means any place outside the home accommodation: a haystack, a mighty oak, a hunting, a fishing, a mowing, a building, a street itself. The public places are conventionally divided into two groups: a) those intended for the alcohol drinking (the restaurants, the taverns, the bars, the pubs) and b) those where alcohol drinking is prohibited (the railway stations, the cinemas, etc.). Accommodations are the houses, the apartments, where the character's kitchen plays the role of the special locus, or the place is represented very broadly - be visiting something.

We can say that in the anecdote Russian people drink everywhere, i.e. foresee SoAD (place and time) in the anecdote is quite difficult.

\section{Russian Life in Chekov's Plays}

In A. P. Chekhov's plays SoAD is the following: the main subjects - the characters of the play: the nobles, the officials, etc., a group of people mostly of one's social status, one nationality, age - from 20 years and older. We can say that in this case fiction text issues from the goals, specify the participation's parameters of the SoAD, so there is no diversity of the subjects of the SoAD as in the anecdote.

In Chekhov's plays both men and women drink (in "the Uncle Vanya" Sonya and Elena Andreevna, in "the Three Sisters" Masha). Note that in the anecdote there are no drinking women, which reflects the male point of the view on this social phenomenon: the woman should not drink. A literary text is a reflection of a real life, so unlike the anecdote here women drink as well. Men do not play the role of condemning minor subjects, opponents of drunkenness, but play the role of sympathetic and understanding confederate subject. Confederate subject is a subjective type of person, non-unique, located with others with relation of a joint activity, cooperation (Shmelova, 1988: 46), as Trigorin or Sorin in "The Seagull":

Маша. Любить безнадежно, иелье годы ждать чего-то...А как выйду замуж, будет уже не до любви, новые заботы заглушат все старое. И все-таки, знаете ли, перемена. Не повторить ли нам?

Тригорин. А не много ли будет?

Маша. Hy, вот! (наливает по рюмке.) $B b l$ не смотрите на меня так. Женщины пьют чаще, чем вы думаете. Меньшинство пьет открыто, как я, а большинство тайно. Да. И все водку или коньяк. (Чокается.) Желаю вам! Вы человек простой, жалко с вами расставаться. Пьют. (A.P. Chekov "The Seagull”).

Or

маша (встает). Завтракать пора, должна быть. (Идет ленивою, вялою походкой.) Ногу отсидела... (Уходит.)

Дорн. Пойдет и перед завтраком две рюмочки пропустит.

Сорин. Личного счастья нет у бедняжки (A.P. Chekov "The Seagull”).

As in the anecdote, the female characters, as a rule, condemn drunkenness, for example, Sonya and Elena Andreevna in the "Uncle Vanya", Irina in the "Three Sisters". It is worth noting that the perception of alcohol drinking for the characters in A. P. Chekhov's play may be polar. Let's compare the monologues of two doctors:

Астров. Обыкновенно, я напиваюсь так один раз в месяи. Когда бываю в таком состоянии, то становлюсь нахальным и наглым до крайности. Мне тогда все нипочем! Я берусь за самые трудные операции и делаю их прекрасно; я рисую самые широкие планы будущего; в это время я уже не кажусь себе чудаком и верю, что приношу человечеству громадную пользу... громадную! И в это время у меня своя собственная философская 
система, и все вы, братиы, представляетесь мне такими букашками... микробами (A.P. Chekhov "Uncle Vanya”).

Чебутыкин. Думают, я доктор, умею лечить всякие болезни, а я не знаю решительно ничего, все позабыл, что знал, ничего не помню, решительно ничего. 〈... (Плачет.) О, если бы не существовать! 〈... Третьего дня разговор в клубе; говорят, Шекспир, Вольтер... Я не читал, совсем не читал, а на лице своем показал, будто читал. И другие тоже, как я. Пошлость! Низость! И та женщиина, что уморил в среду, вспомнилась... и все вспомнилось, и стало на душе гадко, мерзко, пошел, запил... (A.P. Chekhov “Three Sisters").

The heroes of Chekhov's plays, as a rule, drink not very much unlike the heroes of the anecdote. Among the drinks selection is following: the vodka, a wine, champagne, a cognac and a beer. Analysis of the material showed that the heroes of the plays (the male characters) prefer two types of drinks - the vodka and the wine, the women prefer only the wine. I would especially want to stimulate an interest in the champagne, which embodies the holiday celebration, so it is drunk at a wedding ("The Wedding"), at the time of the marriage proposal ("The Offer"), "the scene of the failed marriage proposal of Lopakhin doesn't look illogical: No champagne no marriage proposal" (Ivleva, 2001). The champagne is the index of the idleness life, so the main character in "The Cherry Orchard" characterized her husband in the next way: "I married a man who did nothing but debts. My husband died because of champagne - he drank terribly "(A.P. Chekhov. "The Cherry Orchard"). The researchers associated the champagne with the theme of an end, an unfulfilled lives, that we can see in "The Three Sisters" and "The Cherry Orchard" (Ivleva, 2001). We especially note the beer, which appears only once, in the plays and in the unusual (from the perspective of a connoisseur - impossible) combination: Аркадина. Красное вино и пиво для Бориса Алексеевича ставьте сюда, на стол. Мы будем играть и пить. (A.P. Chekhov "The Seagull"). According to N.I. Ishchuk-Fadeeva this combination is not random: «... beer and wine were considered as poetic metaphors of blood, $<\ldots>$ the blood turns into a strong honey ....» Honey / soma in ancient mythology were a metaphorical symbol of the gods drink, granting immortality. In the Scandinavia poetry honey is a symbol of poetry, in the Russian poetry honey in combination with a beer is the formula of the wedding feast, symbolizing the successful completion of misadventures of heroes. Strikingly, how this mythology is reinterpreted in "The Seagull" (Ishuk-Fadeeva, 2001). Among vessels in A. P. Chekhov's plays in SoAD we can see only a small glass from which characters drink mostly vodka.

The place and the time of SoAD in the dramatic text is not specifically actualized as in the anecdote, because the time of SoAD is specified by time of the play as a true fiction time and place - a real fiction space.

\section{Conclusion}

To summarize, we can note that the aspects of the topic that were not addressed in this paper are exist: it is predicates of SoAD; the reasons and the causes of SoAD, etc. That is why we can appeal to this topic again and again.

Examination of the situation of alcohol drinking at the lessons of Russian as foreign language is possible in the network of the theme "Russian Life", along with the study of peculiarities of cuisine, gastronomy, beverages and Russian feasts (Zinovieva, 2010). For this purpose during the one lesson students can watch prepared in advanced video from E. Ryazanov movie "Irony of the Fate, or I hope 
you enjoyed your bath!", previously worked through a thematic vocabulary associated with the celebration of the New Year, alcohol drinking and feast. Examine the scenarios of the feast and its stages: preparation (shops, food), dishing up, feast, conversations, etc. Carry out the project work: select art works, videos, song associated with Russian feast.

In addition, the situation of alcohol drinking at the lessons of Russian as foreign language can be studied within the project "Russian national drinks", comparing the situation of tea and alcohol drinking in Russian culture: the participants, predicates, the object of drinking, snacks.

Such work at the lessons of Russian as foreign language is important for the students of another (non-European) culture grow up in a different life conditions. That is why it is so important not only to compare information that students get from the dictionaries, but to complete it. In addition, semantization of vocabulary of specific group must be accompanied by an explanation, involving historical and etymological information that will help to make the words, designating specific reality and concepts, understandable.

\section{References}

1. Vasiliev A.G. To lingvoculturological parameters: who are we? Intercultural Communication and the problems of national identity. Voronezh: Voronezh State University, Publishing House, 2002, p. 48-54.

2. Zinovieva E.I. Russian mentality in the mirror of language. Saint-Petersburg.: Publishing House Nestor - Istoriya, 2010.

3. Ivleva T.G. Champaign in the art world of A.P. Chekov, the literary text: problems and methods of study - 8. The motif of wine in the literature. Tver: Tver State University, 2001, p. 52-59.

4. Ishuk-Fadeeva N.I. Dionisism of the chekov theatre, the literary text: problems and methods of study -8 . The motif of wine in the literature. Tver: Tver State University, 2001, p. 45-51.

5. Koboseva I.M. Linguistic Semantics. M.: Editorial, 2002.

6. Levontina I. Where is the glass? About spiritual pleasers Stengazeta. Net. M., 2009, $1^{\text {st }}$ of October.

7. Michailova U.N. Russia as a myth, Rodina. № 10. M., 2005, p. 23-36.

8. Pochlebkin V.V. Tea and vodka in the history of Russia. Krasnoyarsk: Krasnoyarsk publishing house; Novosibirsk publishing house, 1995.

9. Russian verbal sentences: Experimental syntactic dictionary. M: Flinta: Science, 2002.

10. Stepanov U.S., Vodka and Drunkenness, Constants: Dictionary of Russian culture. M.: Academic Project, 2001.

11. Tarasenko T.V. Situation of alcohol drinking and its reflection in the anecdotes. Projects for comparative study of Russian and other languages. Belgrade: Чигоја штампа, 2004, p.179-184.

12. Tarasenko T.V. The joke as a phenomenon of the language and culture, Studia Rossica Posnaniensia, vol. XXXII. Poznan: Wydawnictwo Naukove Uniwersytetu im. Adama Mickewicza, 2005, p. 161-172.

13. Shmelova T.V. Semantic Syntax. Krasnoyarsk: Krasnoyarsk State University, 1988.

14. Shor U.M. The experience of everyday life, The phenomenon of everyday life: human studies. Philosophy. Culture studies. History. Филология. Art. Saint-Petersburg.: Asterion, 2005, p. 5-9. 
15. Shegoleva U. The stereotype of a positive hero in the traditional culture and modern mass consciousness, Russians and "Russianness": Linguistic-cultural studies. M.: Gnosis, 2006, p. 179262.

\section{Семантика русского быта}

\section{на уроках русского как иностранного \\ (лингвистический и методический аспекты)}

Т.В. Тарасенко

Сибирский государственный аэрокосмический университет

Россия, 660037, Красноярск

пр. им. газеты "Красноярский рабочий", 31

В статье рассматривается русский быт через семантику ситуации винопития, анализируется лингвистический аспект ситуации винопития, представлена методика изучения ситуации на уроках РКИ. Материалом послужили анекдоты, пьесы А.П. Чехова.

Ключевые слова: русский быт, ситуация, семантика, анекдот, А.П. Чехов, пьесы, методика преподавания, РКИ.

Научная специильность: 10.00.00 - филологические науки. 